NoRBERT LAURISZ

Uniwersytet Ekonomiczny w Krakowie, Polska - Cracow University of Economics, Poland

\title{
W kierunku komercjalizacji działalności społecznej - różnicowanie sposobu prowadzenia działalności przez podmioty ekonomii społecznej w efekcie ich ekonomizacji
}

\section{Towards the Commercialisation of Social Activities - Differentiating of Mode of Operation by Social Economy Organisations as a Result of their Marketisation}

\begin{abstract}
Streszczenie: Coraz więcej podmiotów ekonomii społecznej (PES) przechodzi przez proces ekonomizacji. W Polsce proces ten jest inicjowany głównie przez państwo i prowadzoną przez nie politykę, której celem jest podniesienie samodzielności i niezależności PES. Ekonomizacja wywołuje zmiany w sposobie działania podmiotów pochodzących z III sektora. Poniższy artykuł jest próbą ilustracji tego zjawiska przy wykorzystaniu analizy kokreacji. Celem artykułu jest prezentacja odmiennych sposobów prowadzenia działalności przez PES, co jest efektem ich ekonomizacji. Artykuł powstał w efekcie studiów nad literaturą oraz na podstawie badań na grupie PES - uczestników projektu „Małopolski Ośrodek Wsparcia Ekonomii Społecznej” (MOWES). Najważniejszym wnioskiem z przeprowadzonych badań jest rozpoznanie różnic w stosowaniu kokreacji w przypadku różnych typów prowadzenia działalności przez ekonomizujące się podmioty ekonomii społecznej. Różnica ta jest efektem innego podejścia PES do działalności gospodarczej i działalności odpłatnej. Przeprowadzone badania pokazują, że zakres kokreacji zmienia się wraz ze zmianą rodzaju działalności: im działalność bardziej się ekonomizuje, tym zakres kokreacji jest mniejszy. Ekonomizacja zmienia otwarty model współpracy charakterystyczny dla działalności misyjnej na bardziej zamknięty model działania w przypadku prowadzenia działalności odpłatnej czy gospodarczej.
\end{abstract}

\begin{abstract}
An increasing number of social economy organisations (SEOs) is undergoing marketisation. In Poland this process is initiated mainly by the state and its policy, which aims to increase the independence of SEOs. Marketisation causes changes in these entities' mode of operation. The present article illustrates this phenomenon using co-creation analysis. The aim of the article is to present a different approach to the activities carried out by SEOs, which is the result of their marketization. The article was created as a result of the literature studies and the research carried out on a group of SEOs - participants of the MOWES project. The most important conclusion from the research is determining the differences
\end{abstract}


in the use of co-creation in the case of different types of activities conducted by economising social economy entities. The research shows that the scope of co-creation changes with the change of activity. The greater the marketisation of SEOs activities, the smaller the co-creation. Marketisation changes the open cooperation model to a more closed operating model.

Słowa kluczowe: ekonomizacja; kokreacja; komercjalizacja; NGO; organizacje pozarządowe; PES; podmioty ekonomii społecznej; przedsiębiorstwo społeczne

Keywords: co-creation; commercialisation; economization; marketisation; NGO; non-governmental organisations; SEOs; social economy organisations; social enterprise

Otrzymano: 24 listopada 2019

Received: 24 November 2019

Zaakceptowano: 20 kwietnia 2020

Accepted: 20 April 2020

\section{Sugerowana cytacja/Suggested citation:}

Laurisz, N. (2019). W kierunku komercjalizacji działalności społecznej - różnicowanie sposobu prowadzenia działalności przez podmioty ekonomii społecznej w efekcie ich ekonomizacji. Przedsiębiorczość - Edukacja [Entrepreneurship - Education], 16(2), 189-201. doi: $10.24917 / 20833296.162 .15$

\section{Wstęp}

Niniejszy artykuł jest pierwszym z serii artykułów opisujących zmiany zachodzące w podmiotach ekonomii społecznej (PES) w efekcie ich ekonomizacji. W prezentowanych analizach wykorzystano wyniki badań podmiotów uczestniczących w projekcie „Małopolski Ośrodek Wsparcia Ekonomii Społecznej” (MOWES), którego celem była ekonomizacja PES.

Podmioty działające w sektorze ekonomii społecznej charakteryzuje działalność misyjna. Równolegle podmioty te starają się prowadzić działalność odpłatną (statutową) oraz działalność gospodarczą w celu dywersyfikacja dochodów i - w efekcie - stabilizacji działalności podmiotu. W tym miejscu warto podkreślić, że ważnym, aczkolwiek egzogenicznym czynnikiem jest działalność państwa próbującego realizować politykę, której efektem ma być rozwój, usamodzielnienie i stabilizacja działalności podmiotów ekonomii społecznej (PES). Polityka ta stała się wyzwaniem zarówno dla państwa, jak i dla wspieranych podmiotów. W tym kontekście zauważalne jest, że polityka państwa przyczynia się do powstawania zewnętrznej i wewnętrznej presji na ekonomiczne usamodzielnianie się PES. W ten sposób, za pomocą „kija i marchewki”, w sferę realizacji celów społecznych wprowadzony zostaje komponent ekonomiczny. Z tego też powodu kluczowym elementem analiz stało się ustalenie kierunku zmian zachodzących zarówno w całym sektorze, jak i w poszczególnych podmiotach oraz znalezienie odpowiedzi pytanie: Czy podmioty te powinny stawać się bardziej rynkowe i realizować cele gospodarcze, aby osiągać niezależność i stabilność gwarantującą rozwój, czy też cele gospodarcze powinny realizować jedynie dodatkowo, a najważniejsze dla nich powinny być cele społeczne niezależnie od tego, że ich realizacja powoduje deficyt? Zaproponowana w poniższym tekście analiza ma na celu przedstawienie, jak ekonomizacja działalności PES różnicuje sposób prowadzenia przez te podmioty działalności. 
W Polsce za podmiot ekonomii społecznej uznaje się każdy podmiot działający zarówno gospodarczo, jak i społecznie oraz realizujący cele społeczne. Oznacza to wykorzystanie bardzo szerokiej definicji ekonomii społecznej i przedsiębiorstwa społecznego (Pacut, 2010; Perrini, 2006). Według tego poglądu przedsiębiorstwem społecznym w Polsce jest każdy podmiot realizujący cele społeczne, który wprowadza do obrotu produkty lub usługi - niezależnie od tego, czy ma na celu wygenerowanie zysku (Hausner, Laurisz, Mazur, 2007; Wygnański, Frączak, 2008). Pokazuje to silny trend w idei ekonomizacji działalności społecznej i wręcz sektorowego wymuszania tego typu postaw na podmiotach realizujących działalność misyjną. W efekcie takich interpretacji, jak również tak tworzonej polityki publicznej, organizacje pozarządowe realizujące jedynie działalność statutową (poza formą nieodpłatną także w formie odpłatnej) również uznawane są za przedsiębiorstwa społeczne. Powoduje to, że większość podmiotów III sektora staje się równocześnie podmiotami ekonomii społecznej, które w Polsce w wielu aspektach traktowane są jak przedsiębiorstwa.

Ekonomizacja podmiotów działających społecznie jest rozumiana jako wprowadzenie mechanizmów gospodarczych i/lub rachunku ekonomicznego do działalności podmiotu (Wygnański, 2008; Wygnański, Frączak, 2008). W efekcie ekonomizacji podmioty III sektora rozpoczynają prowadzenie działalności odpłatnej i równie często rozpoczynają prowadzenie działalności gospodarczej. Polska nie jest wyjątkiem - jak można zauważyć w krajach całej Europy działalność społeczna się ekonomizuje (Schwenger, Straub, Borzillo, 2013). Badania i analizy pokazują, że konsekwentne wdrażanie polityki wzmacniającej ekonomiczną samodzielność podmiotów (Mikołajczak, 2017), podobnie jak zwiększanie presji na organizacje pozarządowe w celu ich ekonomizacji, prowadzi do poszerzania działalności przez PES, jak również do zmian w sposobie ich działania (Nunnenkamp, Öhler, 2010).

W tym kontekście powstaje pytanie, w jaki sposób te zmiany wpływają na podmioty oraz na ich relacje $\mathrm{z}$ otoczeniem. $Z$ tej perspektywy relacje $\mathrm{z}$ konsumentami i pozostałymi kluczowymi interesariuszami rozumiane jako szeroko pojęta kokreacja stają się intersującym narzędziem badawczym, a zmieniający się w efekcie tego model biznesowy staje się obszarem badań i analiz. Aby zatem można było omówić zagadnienia dotyczące różnic w sposobach działania ekonomizujących się podmiotów ekonomii społecznej, przeprowadzona została analiza, której celem jest ilustracja relacji pomiędzy badanymi podmiotami a interesariuszami, w tym, co należy podkreślić, z konsumentami - grupą ważną, aczkolwiek często pomijaną w analizie interesariuszy.

\section{Kokreacja}

Zmiany technologiczne wywołują czasową niestabilność na rynku dóbr i usług oraz wpływają na relacje pomiędzy konsumentami a producentami. Zmiany te, szczególnie w zakresie technologii informacyjnych i komunikacyjnych, powodują rosnącą niestabilność odbiorców względem marek i produktów. Z tej perspektywy badacze podkreślają, że konieczna jest pewna korekta rozwiązań zarządczych i skierowanie ich w stronę modelu współtworzenia, w ramach którego strony: popytowa i podażowa szeroko współpracują ze sobą w celu osiągnięcia lepszych niż dotąd rezultatów (Ramaswamy, Ozcan, 2014). Podkreśla się, że zmiana musi nastąpić w orientacji procesu tworzenia wartości z orien- 
tacji produktowej (product-oriented) na orientację na konsumenta (customer-oriented), czasem prezentowanej w szerszym ujęciu jako orientacja na usługi (service-oriented) (Prahalad, Ramaswamy, 2004; Vargo, Lusch, 2004; Vargo, Maglio, Akaka, 2008). W efekcie potrzebne jest wpływanie na kierunek rozwoju w taki sposób, aby podmioty działające na rynku były usieciowione i współzależne (interdependent), a proces tworzenia wartości łączył ze sobą producentów, konsumentów i innych interesariuszy (Olson, Lee, Trimi, 2012). Ten nowy model, nazwany kokreacją (co-creation), polega na zmianie sposobu myślenia o potrzebach konsumenta i reorientacji procesu tworzenia produktów, usług $\mathrm{i}$ innowacji.

Z perspektywy podmiotu gospodarującego kokreacja jest działaniem wspólnym prowadzonym w celu uzyskania lepszego produktu końcowego (Galvagno, Dalli, 2014). Nowa droga w tworzeniu rozwiązań podnoszących jakość oferowanych produktów jak również lojalność, przywiązanie i zaufanie klientów polega na zmianie sposobu myślenia o potrzebach konsumenta i reorientacji procesu tworzenia produktów, usług i innowacji. Odpowiedzią na to są działania nakierowujące proces tworzenia produktów końcowych na konsumenta (von Hippel, 1987; Voorberg, Bekkers, Tummers, 2015). Oznacza to wyjście poza ramy wewnętrznej kreacji rozwiązań oraz szeroko pojętej koprodukcji i zaangażowanie w proces tworzenia, testowania i ulepszania oferowanych rozwiązań jak największej liczby interesariuszy, w tym przede wszystkim konsumentów (Kazadi, Lievens, Mahr, 2016). Kokreacja jako sposób działania podmiotów rynkowych zaczyna być zauważalnym sposobem reagowania na zachodzące zmiany na rynku i w otoczeniu rynkowym (Olson, Lee, Trimi, 2012). Interesującym aspektem tego zagadnienia jest występowanie zjawiska kokreacji w podmiotach do tego zdecydowanie bardziej predystynowanych, czyli w podmiotach działających w obszarze ekonomii społecznej.

Kokreacja prezentowana jest w poniższym tekście jako jeden z nowych paradygmatów, w którym w zarządzaniu celem jest tworzenie wartości w efekcie aktywnej współpracy pomiędzy wytwórcami a konsumentami (Galvagno, Dalli, 2014). W sposób najprostszy i zarazem najszerszy kokreację definiuję się jako nakierowanie procesu tworzenia wartości na konsumenta (Ramaswamy, Ozcan, 2014). Oznacza to zamianę zamkniętych lub półotwartych procesów wewnętrznych na otwarty proces, w którym najważniejszą rolę przyjmuje konsument jako najistotniejszy z interesariuszy. Ten nowy model wymaga szerokiego i aktywnego forum współpracy pomiędzy wszystkimi podmiotami na poziomie mikro, jak i na poziomach wyższych (Prahalad, Ramaswamy, 2004). Warunkiem koniecznym zaistnienia tego modelu, jego wdrożenia i rozwoju, jest aktywna rola podmiotów rynkowych, organizacji rzeczniczych, jak i poszczególnych jednostek

Niezauważalnym, ale bardzo ważnym aspektem modelu kokreacji jest fakt, że jest on obecny w działalności podmiotów ekonomii społecznej. Codzienne prowadzenie działalności polega na szerokiej współpracy z interesariuszami. Proces powstawania innowacji społecznej jest efektem kooperacji z konsumentami, władzą publiczną i innymi interesariuszami (Bitzer, Glasbergen, 2015; Dahan i in., 2010). W efekcie tych wspólnych działań powstaje wartość społeczna (Gouillart, 2014; Pinho i in., 2014). Oznacza to, że działalność prowadzona przez podmioty społeczne, podobnie jak i kokreacja, jest silnie zorientowana na konsumenta oraz na tworzenie nowych rozwiązań, w tym innowacji społecznych (Galvagno, Dalli, 2014).

W tym miejscu należy podkreślić jeszcze dwa kluczowe aspekty występowania kokreacji $\mathrm{w}$ podmiotach społecznych. Pierwszym z nich jest tworzenie wartości społecznej 
i innowacji społecznych, drugim - uczestnictwo w łańcuchu wartości. Praktyka pokazuje, że szeroka współpraca $\mathrm{z}$ interesariuszami skutkuje większą innowacyjnością (Phills, Deiglmeier, Miller, 2008). Natomiast poszerzenie grona interesariuszy o podmioty ekonomii społecznej otwiera nowe drogi dla tworzenia wartości i wpływa pozytywnie na efekt końcowy procesu tworzenia (Dahan i in., 2010). Badania pokazują, że współpraca międzysektorowa (państwo, rynek, społeczeństwo) przynosi korzyści każdemu z uczestników współpracy, a wzrost efektywności i spadek ryzyka jest obserwowany na każdym etapie tworzenia łańcucha wartości (Bitzer, Glasbergen, 2015).

\section{Uczestnicy procesu kokreacji}

Na podstawie teorii interesariuszy (Freeman, 2010; Harrison, 2014; Parmar i in., 2010) oraz zdefiniowanej roli aktorów kokreacji (Leclercq, Hammedi, Poncin, 2016) można zidentyfikować grupę kluczowych i zarazem najbardziej wpływowych uczestników procesu tworzenia wartości, w trakcie którego powstaje oczekiwany i pożądany efekt - tym efektem może być produkt, usługa, innowacja produktowa czy procesowa. Ogólnie przyjmuje się, że efektem tym jest wartość oczekiwana przez podmioty realizujące proces.

W przypadku PES do najważniejszych uczestników procesu tworzenia wartości należą: biznes, który m.in. pomaga w tworzeniu konkurencyjnej oferty, oraz państwo, które wspiera instytucjonalnie PES, jak również umożliwia realizację misji przez wdrażanie odpowiedniej polityki publicznej (Bryson i in., 2017; Bryson, 2004; Hausner, Laurisz, Mazur, 2007). Trzecim kluczowym uczestnikiem tego procesu jest konsument, jednak, co należy podkreślić, warunkiem koniecznym skuteczności procesu jest wysoki stopień aktywności jego uczestników (Prahalad, Ramaswamy, 2004; Ramaswamy, Gouillart, 2010). W ten sposób tworzone są sieci współpracy, które składają się z wielu elementów. Tworząc silnie zdywersyfikowane i wielowymiarowe konstrukcje, odchodzi się od scentralizowanych konglomeratów, o trwałości procesowej uzależnionej od trwania projektu, na rzecz rozwiązań długotrwałych, w których współpraca trwa i rozwija się wielokierunkowo nawet po zakończeniu zadania (Gummesson, Mele, 2010).

Ważnym faktorem jest rola państwa w procesie systemowego rozwoju sektora ekonomii społecznej. Państwo współpracuje z sektorem społecznym oraz wspiera realizację misji podmiotów społecznych. Odbywa się to głównie przez finansowanie ze środków publicznych realizacji celów statutowych lub też przez kontraktowanie usług publicznych (Bohdziewicz-Lulewicz, Rychły-Mierzwa, 2018). Oprócz tego państwo wdraża działania mające na celu wspieranie samodzielności i samowystarczalności PES. Celem państwa jest wepchnięcie PES na tory ekonomizacji, która w założeniu stanie się kołem zamachowym dla ich samodzielności i samowystarczalności (Bohdziewicz-Lulewicz, Krupnik, 2014). Ważne jest, że wsparcie to jest kierowane do wszystkich podmiotów III sektora w taki sposób, aby zwiększyć liczbę przedsiębiorstw społecznych tworzonych przede wszystkim przez przemianę NGO realizujących działania społeczne w podmioty w części działające rynkowo (Perrini, 2006). Przy czym działalność gospodarcza nie musi stanowić podstawy działalności tych podmiotów, ale powinna być czynnikiem wpływającym na podniesienie zdolności do zmian sposobu działania w kierunku zwiększenia samodzielności (Laurisz, Mazur, 2008). Proces ten wpływa na zmianę roli jednego z uczestników oraz na zmianę samych PES, które w efekcie polityki państwa reorientują swój sposób działania przez przesuwanie akcentu w sposobie działania w stronę modelu rynkowego. 
Metodyka badań

Pierwszym kluczowym etapem prowadzonej analizy był dobór interesariuszy. Został on przeprowadzony na podstawie warunków dotyczących ograniczonej skali wpływu interesariuszy (Ćwiklicki, 2011). Kluczowym kryterium decydującym, czy dany uczestnik został uwzględniony w analizie, była ważność jego obecności w procesie tworzenia wartości, rozumiana jako komplementarność zasobów i/lub zdolności w łańcuchu wartości (Bitzer, Glasbergen, 2015).

Metodologia wykorzystywana do selekcji kluczowych interesariuszy pozwoliła na przeanalizowanie uczestników procesu w badaniach prowadzonych na uczestnikach projektu „Małopolski Ośrodek Wsparcia Ekonomii Społecznej”, realizowanego w województwie małopolskim w latach 2016-2019. Tworzenie mapy interesariuszy było elementem pierwszego etapu diagnozy każdego z podmiotów. Podczas selekcji i mapowania wykorzystane zostały macierze wpływu i oddziaływania interesariuszy: krąg interesariuszy wg Bourne’a, trójwymiarowa macierz Murraya, Webstera i Simona oraz macierz Imperial College London (Chinyio, Olomolaiye, 2009).

Z perspektywy prowadzonych badań ważnym aspektem okazało się wydzielenie z grupy przedsiębiorstw tych podmiotów, które działają społecznie. W takich przypadkach relacje między NGO a tymi przedsiębiorstwami są partnerskie. W przypadku innych przedsiębiorstw relacje te są głównie charytatywno-biznesowe (Dahan i in., 2010; Hatch, Schultz, 2010). W ten sposób uwzględnione zostały ważne przesłanki, które w dalszych badaniach implikowały przeprowadzenie dekompozycji w kontekście występowania różnych ról uczestników w zależności od sposobu czy profilu działania. W efekcie lista kluczowych podmiotów zaangażowanych w proces tworzenia wartości (kluczowych interesariuszy) przyjęła kształt przedstawiony w tabeli 1.

Tabela 1. Kluczowi interesariusze wskazani przez badane podmioty $(n=112)$.

\begin{tabular}{|l|c|}
\hline \multicolumn{1}{|c|}{ Interesariusze } & Liczba wskazań \\
\hline Konsumenci & 87 \\
\hline Samorząd gminy & 85 \\
\hline Członkowie stowarzyszeń & 92 \\
\hline NGO - konkurencyjne & 78 \\
\hline NGO - wspierające systemowo działalność PES & 81 \\
\hline Przedsiębiorstwa działające społecznie & 76 \\
\hline Wolontariusze & 88 \\
\hline
\end{tabular}

Źródło: badania własne

Głównym celem prowadzonych badań w ramach projektu MOWES była analiza zakresu rozwoju ekonomicznego podmiotów. Jednym z elementów tej analizy było badanie zakresu współpracy między podmiotami zaangażowanymi w proces tworzenia wartości. Badanie to było trzyetapowe, a każdy etap stanowił obligatoryjny element sprawozdawczości podmiotów - uczestników projektu MOWES. Natomiast formuła badania została poszerzona na potrzeby badań dotyczących zmian wynikających z procesu ekonomizacji. Do etapów tych należały: 1) Wstępna analiza sytuacji podmiotu wykonywana na potrzeby indywidualizacji i profilowania wsparcia dla każdego z podmiotów; 2) Monitoring 
wdrożenia wsparcia oraz analiza postępu zmian w działalności podmiotów; 3) Badanie satysfakcji podmiotów po zakończeniu wsparcia. W badaniach tych sprawdzane były istotne aspekty funkcjonowania uczestników projektu MOWES, w tym m.in. te dotyczące zmian wynikających z wdrożenia wsparcia nakierowanego na ekonomizację, jak również relacji z kluczowymi interesariuszami.

Każdemu podmiotowi (przedstawicielowi podmiotu) zadano trzy pytania:

1. Jaki rodzaj kooperacji z kluczowymi interesariuszami dominuje w Państwa statutowej nieodpłatnej działalności?

2. Jaki rodzaj kooperacji z kluczowymi interesariuszami dominuje w Państwa statutowej odpłatnej działalności?

3. Jaki rodzaj kooperacji z kluczowymi interesariuszami dominuje w Państwa działalności gospodarczej?

Dla każdego rodzaju działalności PES respondent mógł wybrać dwie odpowiedzi, gdzie 1 oznaczało najczęściej występującą formę zaangażowania kluczowych interesariuszy w proces tworzenia wartości, natomiast 2 - drugą co do popularności/częstości formę zaangażowania. Oznacza to, że każdy respondent zaznaczał dwie odpowiedzi dla każdego rodzaju prowadzonej przez dany podmiot działalności. W tabeli 2 zaprezentowano rozkład odpowiedzi z ostatniego badania podmiotów w projekcie MOWES (badania satysfakcji). Ewaluacja projektu wykazała, że najwyższy poziom rozumienia zasad prowadzenia działalności przez PES i znajomości samego sposobu wspierania oraz rozwoju podmiotów, od strony narzędzi, form wsparcia, celów oraz skutków wdrążanych działań, był wśród podmiotów kończących udział w projekcie.

W badaniach uczestniczyły 112 podmioty, ale, co warto podkreślić, tylko 64 podmioty prowadziły każdą z analizowanych form działalności. Do prezentacji wyników badań wykorzystano tylko jedną wartość ze statystyk opisowych, tj. dominantę. Wynikało to z faktu wysokiej reprezentatywności wyników względem innych miar. Dominanta zaprezentowana została dla wskazania numer 1 i wskazania numer 2. Aby lepiej zilustrować uzyskane wyniki, oprócz liczebności wskazań (wartości liczbowe dominanty w nawiasach) zaproponowano prezentację za pomocą znaków, gdzie „XX” wskazuje dominującą odpowiedź dla pierwszego wyboru, natomiast „X” wartość dominującą dla wyboru drugiego (tabela 2).

Różne próby klasyfikacji procesu kokreacji pozwoliły na wykorzystanie w badaniach i następnie $\mathrm{w}$ poniższym tekście podejścia znanego z obszaru partycypacji społecznej, opisującego relację obywatel - władza samorządowa, do badań nad zakresem kokreacji w działalności podmiotów ekonomii społecznej (Bryson i in., 2017; Dahan i in., 2010; O’Hern, Rindfleisch, 2010; Prahalad, Ramaswamy, 2004; Voorberg i in. 2017; Voorberg, Bekkers, Tummers, 2015). Przeprowadzona na podstawie badań analiza procesu kokreacji oparta została na skróconej, pięciostopniowej skali zaangażowania (tabela 2). W analizie zastosowane zostały następujące kategorie: 1) brak uczestnictwa, 2) stworzenie możliwości uczestnictwa, 3) aktywowanie, 4) zaangażowanie w proces, 5) równoprawne uczestnictwo.

\section{Wyniki badań}

Przeprowadzone badania pokazują, że badane podmioty ekonomii społecznej w ramach prowadzonych przez siebie działań współpracują z kluczowymi interesariuszami, w tym z konsumentami swoich usług. W tym kontekście poruszone wcześniej zagadnienie 
o wysokim poziomie współpracy podmiotów ekonomii społecznej z interesariuszami oraz o występującej kokreacji w działalności podmiotów sektora ekonomii społecznej znajduje odzwierciedlenie w wynikach przeprowadzonych badań.

Tabela 2. Angażowanie konsumentów w proces tworzenia wartości przez PES dla każdego z typów działalności

\begin{tabular}{|l|c|c|c|c|c|}
\hline \multirow{2}{*}{$\begin{array}{c}\text { Rodzaj } \\
\text { działaności }\end{array}$} & $\begin{array}{c}\text { Zakres zaangażowania } \\
\text { uczestnictwa }\end{array}$ & $\begin{array}{c}\text { stworzenie } \\
\text { możliwości } \\
\text { uczestnictwa }\end{array}$ & aktywowanie & $\begin{array}{c}\text { zaangażowanie } \\
\text { w proces }\end{array}$ & $\begin{array}{c}\text { równoprawne } \\
\text { uczestnictwo }\end{array}$ \\
\hline $\begin{array}{l}\text { Działalność } \\
\text { statutowa }\end{array}$ & & & & $\mathrm{XX}$ & $\mathrm{X}$ \\
\hline $\begin{array}{l}\text { Działalność } \\
\text { statutowa } \\
\text { odpłatna }\end{array}$ & & & & $(59)$ & $(49)$ \\
\hline & & & $\mathrm{X}$ & $\mathrm{XX}$ & \\
\hline $\begin{array}{l}\text { Działalność } \\
\text { gospodarcza }\end{array}$ & $\mathrm{X}$ & $\mathrm{XX}$ & $(57)$ & $(52)$ & \\
\cline { 2 - 6 } & $(49)$ & $(61)$ & & & \\
\hline
\end{tabular}

Źródło: badania własne

Wyniki badań pokazują różnicę między sposobem podejmowania współpracy z interesariuszami w zależności od rodzaju działalności. Można zauważyć, że w przypadku działalności statutowej PES wykazywały otwarte podejście do swoich interesariuszy. „Zaangażowanie w proces” było wskazane jako pierwszy wybór, a „równoprawne uczestnictwo" było drugim wyborem dla zdecydowanej większości respondentów w przypadku działalności nieodpłatnej. W przypadku działalności statutowej odpłatnej drugim wyborem było „aktywowanie” interesariuszy do uczestnictwa. Ze względu na otwarte podejście do swoich działań, PES korzystają z szerokiej współpracy interesariuszy przy tworzeniu usług i/lub produktów. Odpłatność zmienia postawę PES względem zaangażowania interesariuszy w proces powstawania produktów lub usług w stosunku do działalności nieodpłatnej. W porównaniu z sytuacją, w której nie ma płatnych działań, rola interesariuszy staje się bardziej ograniczona. Jednak największa różnica w postrzeganiu roli interesariuszy występuje w sytuacji prowadzenia przez podmiot działalności gospodarczej. Podmioty prowadzące działalność gospodarczą, w przeciwieństwie do podmiotów prowadzących działalność statutową, ograniczają udział interesariuszy w tworzeniu towarów i usług dla tego rodzaju dzielności.

Podczas analizy wyników można zauważyć ważny fakt umiejscowienia najwyższego poziomu zaangażowania kluczowych interesariuszy w działalność statutową (odpłatną i nieodpłatną), która stanowi podstawę i sedno działalności podmiotów ekonomii społecznej. Z przedstawionych wyników badań można wyciągnąć wniosek, że w grupie badanych podmiotów ekonomii społecznej kokreacja jest zjawiskiem naturalnym. W przypadku działalności statutowej zaangażowanie konsumentów i innych interesariuszy w proces tworzenia wartości można określić jako głęboki - wynika to z faktu, że uczestnicy „uczestniczą równoprawnie” w tworzeniu wartości, jak również są „zaangażowani w proces tworzenia” i „aktywowani do współpracy”. Inaczej wygląda to w przypadku działalności gospodarczej, gdzie można zauważyć „tworzenie możliwości uczestnictwa” oraz „brak uczestnictwa” (tabela 2). 
Podmioty ekonomii społecznej w sposób zdecydowany wykorzystują zaangażowanie uczestników kokreacji w modelu tworzenia wartości. Podmioty społeczne najsilniej angażują uczestników w ramach działalności statutowej - „równoprawne uczestnictwo” to formuła przeznaczona dla działalności statutowej nieodpłatnej podobnie jak „zaangażowanie w proces". Zaangażowanie konsumentów i pozostałych interesariuszy w proces tworzenia wartości w 90\% jest domeną działalności statutowej (107 wskazań, a tylko $12 \mathrm{w}$ przypadku działalności gospodarczej). Na przeciwnym biegunie znajduje się brak uczestnictwa w tym przypadku prawie $80 \%$ wskazań charakteryzuje działalność gospodarczą.

Analizując stopień zaangażowania interesariuszy, widać, że w badanej grupie działalność statutowa silnie angażuje uczestników. Zaobserwowano przy tym nieznaczne zróżnicowanie podejścia do współpracy w przypadku rozróżnienia pomiędzy działalnością statutową odpłatną i nieodpłatną. Dla usług nieodpłatnych widoczne było preferowanie silnego zaangażowania interesariuszy w tworzenie oraz realizację usług. W przypadku odpłatności dominującą odpowiedzią było nadal „zaangażowanie w proces”, jednak coraz bardziej uwidoczniał się wzrost postaw słabiej angażujących interesariuszy, takich jak „aktywowanie”.

W tym ujęciu najbardziej widoczną zmianą i zarazem najbardziej interesującym aspektem tak przeprowadzonej analizy jest zdecydowanie inny stopień angażowania interesariuszy przez badane podmioty w przypadku prowadzenia działalności gospodarczej. Badania na grupie podmiotów prowadzących wszystkie rodzaje działalności - działalność nieodpłatną, odpłatną i gospodarczą - pokazują, że wraz z przechodzeniem do bardziej urynkowionych rodzajów działalności zauważa się inne podejście do angażowania kluczowych interesariuszy w proces tworzenia wartości (tabela 2).

W grupie podmiotów prowadzących działalność nieodpłatną i odpłatną wprowadzenie odpłatności usług wpływa na zmianę sposobu postrzegania interesariuszy. Różnica ta nie jest duża, ale jest widoczna. Wykorzystując kategoryzację zaprezentowaną w tabeli (tabela 2), można zauważyć, że zamiast „równoprawne uczestnictwo” dominującą odpowiedzią stała się odpowiedź „tworzenie możliwości uczestnictwa”. Przedstawiciele badanych podmiotów ekonomii społecznej uznawali, że wprowadzenie odpłatności wnosi do relacji „PES - konsument” nowe elementy: cenę, zysk i koszty. Co oznacza, że relacja współpracy pomiędzy PES a konsumentem zmienia się w relację dwóch stron gry rynkowej. Jednak w przypadku działalności misyjnej nieodpłatnej i odpłatnej menedżerowe PES rozumieją i akceptują uczestnictwo oraz zaangażowanie konsumenta $\mathrm{w}$ tworzenie i realizację usługi. Natomiast w przypadku prowadzenia działalności gospodarczej priorytetem była działalność biznesowa, w której konsument ze współpracownika stał się celem, a często nawet przeciwnikiem. Szczegółowe wyniki badań jakościowych zostaną zaprezentowane w kolejnej publikacji.

\section{Podsumowanie}

Przeprowadzona analiza prezentuje odmienne podejście do kokreacji w tworzeniu wartości w podmiotach ekonomii społecznej w zależności od rodzaju prowadzonej przez nie działalności. Wysoki poziom uczestnictwa i zaangażowania w proces tworzenia wartości przez konsumentów i pozostałych interesariuszy w przypadku działalności misyjnej (statutowej) odzwierciedla spostrzeżenia, że sektor ekonomii społecznej jest miejscem szczególnej współpracy w zakresie tworzenia wartości (Hausner, Laurisz, Mazur, 2007; Pacut, 
2010). Wyjątkowość tej współpracy polega na znacznym zaangażowaniu kluczowych interesariuszy uczestniczących w procesie tworzenia. Prowadząc badania kokreacji w sektorze ekonomii społecznej, zasadne wydaje się stwierdzenie, iż w tej grupie badanych podmiotów kokreacja jest zjawiskiem naturalnym. Potwierdza to znaczny udział osób i podmiotów zewnętrznych zaangażowanych w ten proces. Działalność statutowa nie jest działalnością generująca zyski. Pokazuje to, że podmioty i jednostki zaangażowane w ten proces nie robią tego z powodów materialnych (Pacut, 2010, 2018). Inaczej jest w przypadku kokreacji w sektorze rynkowym, gdzie, jak pokazują badania, zaangażowanie interesariuszy i konsumentów wymaga szeroko zakrojonych działań i ponoszenia kosztów uczestnictwa. Stąd, jak można ocenić, zakres kokreacji w podmiotach rynkowych jest niski (Bitzer, Glasbergen, 2015; Ćwiklicki, 2011, 2015; Dahan i in., 2010; Dargas-Miszczak, 2017; Karwacka, 2013). Rozważania wielu autorów pokazują, że wprowadzanie podmiotów prowadzących działalność społeczną na ścieżkę ekonomizacją, co jest szczególnie widoczne $\mathrm{w}$ polityce państwa, sprawia, że sposób działania tych podmiotów znacząco upodabnia się do sposobu działania podmiotów rynkowych (Dahan i in., 2010; Dentoni, Bitzer, Pascucci, 2016; Eikenberry, Kluver, 2004; Jegorow, 2017; Joy, Shields, 2013; Kaim, 2011; Ramaswamy, Gouillart, 2010; Rymsza, 2013; Rymsza, 2010; Sanders, 2012).

W tym miejscu warto zasygnalizować, że już po zakończeniu projektu przeprowadzone zostały uzupełniające badania jakościowe nakierowane na znalezienie odpowiedzi na pytanie: Z czego wynika ta różnica?. Wyniki badań jakościowych nie zostały opisane w poniższym artykule, gdyż jego celem jest zaproponowanie kokreacji jako narzędzia umożliwiającego badanie procesu ekonomizacji podmiotów prowadzących działalność społeczną i w ten sposób zaprezentowanie i zinterpretowanie wyników przeprowadzonych badań. Prezentacja tych opinii ma jedynie charakter kierunkowy i ma na celu wsparcie interpretacji prezentowanej przez autora. Częściowe wyniki badań jakościowych można znaleźć w artykule J. Laurisz, The Role of Stakeholders in Development of Social Economy Organizations in Poland: An Integrative Approach (2019).

Przeprowadzona analiza pokazuje również, że kokreacja stanowi odpowiednie narzędzie do badania sposobu działania PES w kontekście ich ekonomizacji. Dotychczasowe badania nie uwzględniały kokreacji jako faktora czy nawet zmiennej dekomponującej.

Kokreacja jako model działania PES jest naturalnym sposobem realizacji misji tych podmiotów. Podmioty ekonomii społecznej szeroko wykorzystują zaangażowanie interesariuszy oraz konsumentów w prowadzoną działalność. Konsumenci są ważnym ogniwem w łańcuchu tworzenia wartości. Analiza innych sposobów samofinansowania działalności PES pokazuje, że podmioty te w różnym stopniu angażują uczestników i tym samym, w ramach różnych typów prowadzonej działalności, wykorzystują inny model biznesowy. Wprowadzenie odpłatności, a szczególnie możliwości zarobkowania, zmienia sposób działania badanych PES i zbliża go do modelu biznesowego wykorzystywanego przez podmioty rynkowe. Na pytanie: Czy zasadne jest mówienie o procesie komercjalizacji działalności PES? w tym miejscu nie można udzielić jednoznacznej odpowiedzi, ponieważ zaprezentowane badania mają charakter statyczny. Jednak jest to ilustracja interesującego przykładu odmiennego podejścia do prowadzenia działalności w ramach tego samego podmiotu. Odmienność ta jest bardzo wyraźna, szczególnie jeśli porównujemy prowadzenie działalności gospodarczej z prowadzeniem działalności misyjnej w badaniach podmiotów. Wyraźnie widoczna staje się dwubiegunowość - charakterystyczna struktura działań i współpracy w przypadku działalności misyjnej oraz, po drugiej 
stronie, zbliżanie się do modelu biznesowego charakterystycznego dla podmiotów rynkowych. Wyniki dalszych badań i analiz zastaną zaprezentowane w kolejnych artykułach $\mathrm{w}$ ramach rozpoczętej tym artykułem serii.

Literatura

References

Bitzer, V., Glasbergen, P. (2015). Business-NGO partnerships in global value chains: Part of the solution or part of the problem of sustainable change? Current Opinion in Environmental Sustainability, 12, 35-40. doi: 10.1016/j.cosust.2014.08.012

Bohdziewicz-Lulewicz, M., Krupnik, S. (2014). Regionalny plan rozwoju ekonomii społecznej w województwie małopolskim na lata 2014-2020. Kraków: Regionalny Ośrodek Polityki Społecznej.

Bohdziewicz-Lulewicz, M., Rychły-Mierzwa, A. (2018). Monitoring kondycji sektora ekonomii społecznej w Małopolsce. Kraków: Regionalny Ośrodek Polityki Społecznej.

Bryson, J. (2004). What to do when Stakeholders matter. Public Management Review, 6(1), 21-53. doi: $10.1080 / 14719030410001675722$

Bryson, J., Sancino, A., Benington, J., Sørensen, E. (2017). Towards a multi-actor theory of public value co-creation. Public Management Review, 19(5), 640-654. doi: 10.1080/14719037.2016.1192164

Chinyio, E., Olomolaiye, P. (2009). Construction Stakeholder Management. Oxford: John Wiley Sons.

Ćwiklicki, M. (2015). Maksymalizacja korzyści ze współpracy organizacji pozarządowych z przedsiębiorstwami. Ujęcie metodyczne. Ekonomia Społeczna, 1, 54-65. doi: 10.15678/ES.2015.1.04

Ćwiklicki, M. (2011). Analiza interesariuszy w koncepcji relacji złożonych procesów reakcji. Zeszyty Naukowe. Uniwersytet Ekonomiczny w Poznaniu, 199, 72-80.

Dahan, N.M., Doh, J.P., Oetzel, J., Yaziji, M. (2010). Corporate-NGO Collaboration: Co-creating New Business Models for Developing Markets. Long Range Planning, 43(2-3), 326-342. doi: 10.1016/j. lrp.2009.11.003

Dargas-Miszczak, M. (2017). Współpraca przedsiębiorstw z organizacjami pozarządowymi w Polsce - badanie empiryczne. W: Współczesne wyzwania $w$ zakresie funkcjonowania przedsiębiorstw. Warszawa: Oficyna Wydawnicza SGH.

Dentoni, D., Bitzer, V., Pascucci, S. (2016). Cross Sector Partnerships and the Co-Creation of Dynamic Capabilities for Stakeholder Orientation. Journal of Business Ethics, 135, 35-53. doi: 10.1007/ s10551-015-2728-8

Eikenberry, A.M., Kluver, J.D. (2004). The Marketization of the Nonprofit Sector: Civil Society at Risk?. Public Administration Review, 64(2), 132-140. https://doi.org/10.1111/j.1540-6210.2004.00355.x

Freeman, R.E. (2010). Stakeholder Theory: The State of the Art. Cambridge University Press.

Galvagno, M., Dalli, D. (2014). Theory of value co-creation: A systematic literature review. Managing Service Quality: An International Journal, 24(6), 643-683. doi: 10.1108/MSQ-09-2013-0187

Gouillart, F. (2014). The race to implement co-creation of value with stakeholders: Five approaches to competitive advantage. Strategy and Leadership, 42, 2-8. doi: 10.1108/SL-09-2013-0071

Gummesson, E., Mele, C. (2010). Marketing as Value Co-creation Through Network Interaction and Resource Integration. Journal of Business Market Management, 4, 181-198. doi: 10.1007/s12087010-0044-2

Harrison, J.S. (2014). Strategic Management of Healthcare Organizations: A Stakeholder Management Approach. Business Expert Press.

Hatch, M., Schultz, M. (2010). Toward a theory of brand co-creation with implications for brand governance. Journal of Brand Management, 17. doi: 10.1057/bm.2010.14

Hausner, J., Laurisz, N., Mazur, S. (2007). Przedsiębiorstwo społeczne - konceptualizacja [The concept of social enterprises]. W: Managing Social Economy Institutions. Course Book. Krakow: Małopolska School of Public Administration, Krakow University of Economics. 
Jegorow, D. (2017). Economization of non-government organizations in Poland. Scientific Papers of Silesian University of Technology. Organization and Management Series, 2017(105), 97-108. doi: 10.29119/1641-3466.2017.105.6

Joy, M., Shields, J. (2013). Social Impact Bonds: The Next Phase of Third Sector Marketization?. Canadian Journal of Nonprofit and Social Economy Research, 4(2), 39-55.

Kaim, A. (2011; 2019, 3 października). Przeciwdziałanie ubóstwu i wykluczeniu a komercjalizacja organizacji pozarządowych. Oblicza Biedy we Wspótczesnej Polsce. Pozyskano z: https://www.academia. edu/4440677/Przeciwdzia\%C5\%82anie_ub\%C3\%B3stwu_i_wykluczeniu_a_komercjalizacja_organizacji_pozarz\%C4\%85dowych

Karwacka, M. (2013; 2019, 3 października). Postrzeganie wspólpracy z organizacjami pozarządowymi przez przedsiębiorstwa społecznie odpowiedzialne. Raport z badania. Toruń. Pozyskano z: http:// crnavigator.com/materialy/bazadok/339.pdf

Kazadi, K., Lievens, A., Mahr, D. (2016). Stakeholder co-creation during the innovation process: Identifying capabilities for knowledge creation among multiple stakeholders. Journal of Business Research, 69(2), 525-540. doi: 10.1016/j.jbusres.2015.05.009

Laurisz, N. (2019). The Role of Stakeholders in Development of Social Economy Organizations in Poland: An Integrative Approach. Administrative Sciences, 9(4), 74. doi: 10.3390/admsci9040074

Laurisz, N., Mazur, S. (2008). Kluczowe czynniki rozwoju przedsiębiorczości społecznej. W: A. Giza-Poleszczuk, J. Hausner, Ekonomia społeczna w Polsce: Osiagnięcia, bariery rozwoju i potencjat w świetle wyników badań. Fundacja Inicjatyw Społeczno-Ekonomicznych, 315-331.

Leclercq, T., Hammedi, W., Poncin, I. (2016). Ten years of value cocreation: An integrative review. Recherche et Applications en Marketing (English Edition), 31. doi: 10.1177/2051570716650172

Mikołajczak, P. (2017). Importance of funding sources to the scale of activity of social enterprises. Finanse, Rynki Finansowe, Ubezpieczenia, 88(4/2), 135-144.

Nunnenkamp, P., Öhler, H. (2010). Funding, Competition and the Efficiency of NGOs. An empirical analysis of non-charitable expenditure of US NGOs engagedin foreign aid, 1640.

O’Hern, M.S., Rindfleisch, A.P. (2010). Customer co-creation: A typology and research agenda. Review of Marketing Research, 6, 84-106. doi: 10.1108/S1548-6435(2009)0000006008

Olson, D.L., Lee, S.M., Trimi, S. (2012). Co-innovation: Convergenomics, collaboration, and co-creation for organizational values. Management Decision, 50(5), 817-831. doi: 10.1108/00251741211227528

Pacut, A. (2018). Trajektoria zmian przedsiębiorczości społecznej w Polsce. Ekonomia Społeczna, 2, 7-15. doi: 10.15678/ES.2018.2.01

Pacut, A. (2010). Przedsiębiorczość społeczna w Polsce - problemy i wyzwania. Zarzadzanie Publiczne, $4(14), 45-58$.

Parmar, B., Freeman, R., Harrison, J., Purnell, A., De Colle, S. (2010). Stakeholder Theory: The State of the Art. The Academy of Management Annals, 3, 403-445. doi: 10.1080/19416520.2010.495581

Perrini, F. (2006). The New Social Entrepreneurship: What Awaits Social Entrepreneurial Ventures? Edward Elgar Publishing.

Phills, J., Deiglmeier, K., Miller, D. (2008). Rediscovering Social Innovation. Stanford Social Innovation Review.Pozyskano z: https://www.researchgate.net/profile/James_Phills2/publication/242511521_ Rediscovering_Social_Innovation/links/5630f4d208ae3de9381cd631/Rediscovering-SocialInnovation.pdf

Pinho, N., Beirão, G., Patrício, L., P. Fisk, R. (2014). Understanding value co-creation in complex services with many actors. Journal of Service Management, 25(4), 470-493. doi: 10.1108/JOSM-02-2014-0055

Prahalad, C.K., Ramaswamy, V. (2004). Co-creation experiences: The next practice in value creation. Journal of Interactive Marketing, 18(3), 5-14. doi: 10.1002/dir.20015

Ramaswamy, V., Gouillart, F. (2010). Building the Co-Creative Enterprise. Harvard Business Review, October. Pozyskano z: https://hbr.org/2010/10/building-the-co-creative-enterprise

Ramaswamy, V., Ozcan, K. (2014). The Co-Creation Paradigm. Stanford University Press.

Rymsza, A. (2013). Zagubiona tożsamość? Analiza porównawcza sektora pozarzadowego w Polsce $i$ w Stanach Zjednoczonych. Ministerstwo Pracy i Polityki Społecznej. 
Rymsza, M. (2010). Państwo i sektor obywatelski: Między kulturą kontraktu i kulturą partnerstwa. Trzeci Sektor, 20, 4-6.

Sanders, M.L. (2012). Theorizing Nonprofit Organizations as Contradictory Enterprises: Understanding the Inherent Tensions of Nonprofit Marketization. Management Communication Quarterly, 26(1), 179-185. doi: 10.1177/0893318911423761

Schwenger, D., Straub, T., Borzillo, S. (2013). Competition and Strategy of Non-Governmental Organizations. EMES-SOCENT Conference Selected Papers, 13(4).

Vargo, S.L., Lusch, R.F. (2004). Evolving to a New Dominant Logic for Marketing. Journal of Marketing, 68(1), 1-17. doi: 10.1509/jmkg.68.1.1.24036

Vargo, S.L., Maglio, P.P., Akaka, M.A. (2008). On value and value co-creation: A service systems and service logic perspective. European Management Journal, 26(3), 145-152. doi: 10.1016/j. emj.2008.04.003

von Hippel, E. (1987). Cooperation between rivals: Informal know-how trading. Research Policy, 16(6), 291-302. doi: 10.1016/0048-7333(87)90015-1

Voorberg, W., Bekkers, V., Timeus, K., Tonurist, P., Tummers, L. (2017). Changing public service delivery: Learning in co-creation. Policy and Society, 36(2), 178-194. doi: 10.1080/14494035.2017.1323711

Voorberg, W.H., Bekkers, V.J.J.M., Tummers, L.G. (2015). A Systematic Review of Co-Creation and Co-Production: Embarking on the social innovation journey. Public Management Review, 17(9), 1333-1357. doi: 10.1080/14719037.2014.930505

Wygnański, J., Frączak, P. (2008). The Polish Model of the Social Economy recommendations. Foundation for Social and Economic Initiatives. Pozyskano z: http://portal.ngo.pl/files/ekonomiaspoleczna.pl/ public/socialeconomyinPL/The_Polish_Model_of_the_Social_Economy_recommendations.pdf Wygnański, J. (2008). Ekonomizacja organizacji pozarządowych. Zarządzanie Publiczne, 1(3), 23-61.

Norbert Laurisz, dr nauk ekonomicznych, Uniwersytet Ekonomiczny w Krakowie. Kolegium Gospodarki i Administracji Publicznej, Katedra Zarządzania Organizacjami Publicznymi. Praca naukowa i badania w dziedzinie: polityk publicznych, partycypacji społecznej, ekonomii społecznej, rynku pracy, aktywnej polityki rynku pracy, bezrobocia, grup defaworyzowanych. Jest członkiem zespołu badawczego w projektach naukowych i badawczych w następujących obszarach: rynek pracy i ekonomia społeczna - „Małopolski Ośrodek Wsparcia Ekonomii Społecznej”, „System analizy i programowania rynku pracy”, „Obserwatorium regionalnych rynków pracy”; udział społeczny: „Partycypacja społeczna”, „NAWIKUS - System kontraktowania usług socjalnych w Małopolsce”, „Małopolska Sieć Dialogu Obywatelskiego”.

Norbert Laurisz, PhD, Cracow University of Economics, Collegium of Economy and Public Administration, Department of Management of Public Organisations. He does academic work and research in the field of: public policies, social participation, social economy, labour market, active labour market policy, unemployment, disadvantaged groups. He's a member of the research team in scientific and research projects in the following areas: Labour market and social economy - Social Economy Support Centre, System of analysis and programming of the labour market, Observatory of regional labour markets; public participation - Social participation - a Swiss grant, NAWIKUS - a system for contracting social services in Małopolska, Civic Dialogue Network in Małopolska.

ORCID: https://orcid.org/0000-0003-2079-1041

\section{Adres/Address:}

Uniwersytet Ekonomiczny w Krakowie

Kolegium Gospodarki i Administracji Publicznej

Katedra Zarządzania Organizacjami Publicznymi

ul. Rakowicka 16

31-510 Kraków, Poland

e-mail: norbert.laurisz@uek.krakow.pl 